\title{
A new species of Cerqueirellum Py-Daniel, 1983 (Diptera: Simuliidae) and proven new vector of mansonelliasis from the Ituxi River, Amazon basin, Brazil $^{1}$
}

Felipe Arley Costa PESSOA², Ulysses Carvalho BARBOSA3, Jansen Fernandes MEDEIROS ${ }^{4}$

ABSTRACT

A new species of the genus Cerqueirellum Py-Daniel, 1983 (Diptera: Simuliidae) is described. The adults are similar to the species C. oyapockense (Floch \& Abonnenc, 1946) and C. roraimense (Nunes de Mello, 1974), of which the females are similar, and the males present discrete differences. The main differences of this new species to others of the genus Cerqueirellum are the integument of the larva recovered from stout spines and long cephalic trichomes in the pupa. Some females were infected with Mansonella ozzardii (Manson, 1897) (Nematoda, Onchocercidae) and probably transmit mansonelliasis in the Ituxi river, state of Amazonas, Brazil.

KEY WORDS: Amazônia, Cerqueirellum, Mansonella ozzardi, Simuliidae, taxonomy.

\section{Uma nova espécie de Cerqueirellum Py-Daniel, 1983 (Diptera, Simuliidae) e provável novo vetor de mansonelose no rio Ituxi, Amazonas, Brasil}

\section{RESUMO}

Uma nova espécie de pium do gênero Cerqueirellum Py-Daniel, 1983 (Diptera: Simuliidae) é descrito. Os adultos são similares às espécies C. oyapockense (Floch \& Abonnenc, 1946) e C. roraimense (Nunes de Mello, 1974), cujas fêmeas são indistinguíveis e os machos apresentam discretas diferenças. As principais diferenças dessa nova espécie para as outras espécies do gênero Cerqueirellum são o tegumento da larva recoberto de fortes espinhos e os longos tricomas cefálicos nas pupas. Algumas fêmeas foram encontradas infectadas com Mansonella ozzardi (Manson, 1897) (Nematoda, Onchocercidae) e provavelmente estão transmitindo mansonelose no rio Ituxi, estado do Amazonas, Brasil.

PALAVRAS-ChaVE: Amazônia, Cerqueirellum, Mansonella ozzardi, Simuliidae, taxonomia.

\footnotetext{
1 Project “Perfil Epidemiológico da mansonelose em comunidades ribeirinhas nos municípios de Lábrea, Pauini e Boca do Acre, Amazonas, Brasil”, №2205/05 Financed by Fundação de Amparo à Pesquisa do Estado do Amazonas (FAPEAM).

${ }^{2}$ Biodiversidade em Saúde, Instituto Leônidas e Maria Deane - ILMD/FIOCRUZ, Manaus, AM, Brazil.

${ }^{3}$ Núcleo de Pesquisas em Ciências Humanas e Sociais, Instituto Nacional de Pesquisas da Amazônia - INPA, Manaus, AM, Brazil.

${ }^{4}$ Coordenação de Pesquisas em Ciências da Saúde, Instituto Nacional de Pesquisas da Amazônia, CP 478, 69011-970, Manaus, Amazonas, Brazil. jmedeiro@inpa.gov.br
} 


\section{INTRODUCTION}

The genus Cerqueirellum Py-Daniel is widely distributed in South America, with a single species occurring in Central America (Coscarón \& Coscarón-Árias, 2007). This genus has medical importance because several species are anthropophilic and vectors of at least two filariasis, mansonelliasis and onchocerciasis (Shelley et al., 2006). The adults are very similar in appearance, and sometimes, the females and pupae ornamentation are similar, and only small differences are found in the male scutum and combined characters in the larval forms. The females of the species $C$. oyapockense (Floch \& Abonnenc), C. roraimense (Nunes de Mello) and C. ganalesense (Vargas, Martinez Palacios \& Díaz Nájera) are examples of the similarity of this group (Coscarón \& Coscarón-Árias, 2000). The males of $C$. oyapockense and $C$. roraimense are differentiated by the presence of silver stripes of different length on the scutum; but for populations of $C$. oyapockense from Argentina and C. ganalesense from Mexico, which occur in the northern limits of the Neotropical region, this character is unreliable to differentiate them from $C$. roraimense. In recent excursions to the river Ituxi, an endemic area of mansonelliasis, we collected females similar to $C$. oyapockense biting the local human population. Pupae and larvae collected in these places showed several differences that indicated a new species of the $C$. oyapockense group. This new species is described here.

\section{MATERIAL AND METHODOS}

Study Area: The Ituxi river is a tributary of the Purus river, in the state of Amazonas, Brazil (Figure 1a-c). The Ituxi is 640 $\mathrm{km}$ long, with four major tributaries, namely the Endimari, Curequetê, Ciriquiri and Arauã rivers.

Collections: Sampling was undertaken in two periods in 2007: a week during the rainy season in June, and a week during the dry season in August. Biting females of the new species were caught in several communities, from the high Ituxi river to its outlet (Figure 1c). The immature forms were collected directly from the substrates, tree trunks and roots of the streamside vegetation, and then preserved in commercial $96 \%$ alcohol. Some pupae were maintained alive in a glass vial with a piece of wet filter paper to obtain adults. The adults obtained were pinned. Permanent slides were mounted using synthetic Canada balsam, previously clarified in 10\% $\mathrm{KOH}$. Specimens used in this study are being deposited in the Collection of the Instituto Nacional de Pesquisas da Amazônia (INPA) and in the Biological Collection of the Instituto Leônidas \& Maria Deane-ILMD/FIOCRUZ-AM. The figures of black flies were prepared using a composite image analysis system from the ILMD/FIOCRUZ. The images obtained in this work were stored on CD disks in the Simuliidae archives in the Biological Collection of the ILMD/FIOCRUZ-AM and in the INPA.

The females that were caught biting were placed in test tubes containing $70 \%$ ethanol and identified to species. The black flies were stained with acid hematoxilin and dissected using a stereomicroscope. The head and thorax of each insect were separated on a slide, and examined under a light microscope. When filarial worms were found, we identified

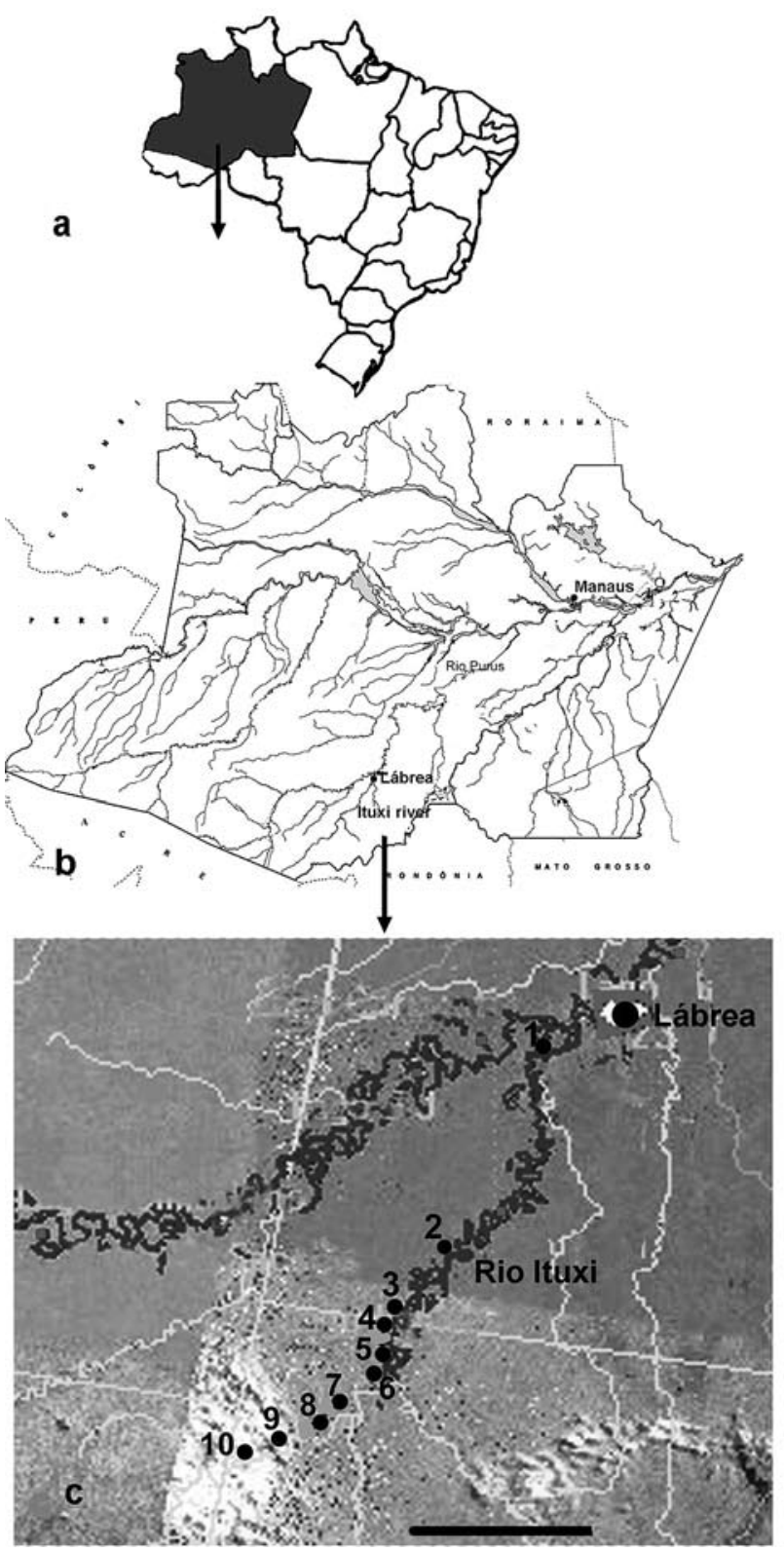

Figure 1 - Maps showing - a: Map of Brazil, dark area indicates the Amazonas State; b: Map of Amazonas State, showing the Ituxi river, and the municipalities of Lábrea and Manaus; c: Increased area of Ituxi river with the areas of the collections of black flies (1: llha Verde, 2: Majuriã, 3: Cajajuriã, 4: São Luis, 5: Cabeçudo, 6: Floresta, 7: Volta do Bucho, 8: Bananal, 9: Pedreira do Amazonas, 10: Capiruã). 
and classified them as to their developmental stage microfilaria (Mf), and larval stages $\mathrm{L}_{1}, \mathrm{~L}_{2}$ or $\mathrm{L}_{3}$. We calculated the Parasitic Infection Rate as the number of black flies parasited by Mansonella ozzardi (Manson) (Nematoda, Onchocercidae) of any stage divided by the total number of females dissected, multiplied by 100 .

The gill formula presented was based on Py-Daniel \& Coscarón (2001). Our material is in accordance with the descriptions of C. oyapockense of Py-Daniel (1983), Shelley et al. (1997, 2002, 2006), Coscarón \& Coscarón-Árias (2000) for adults. Adults, pupae and larvae of $C$. ganalesense, $C$. oyapockense and $C$. roraimense were examined for comparisons with the new species.

\section{DESCRIPTION}

\section{Cerqueirellum pydanieli Pessoa, Medeiros and Barbosa, new species}

(Figures 2-5)

Female - wing length 1.6-2.1 mm $(\mathrm{n}=6, \mathrm{x}=1.7 \mathrm{~mm})$. General coloration blackish, with silver pruinosity. Frons silver iridescent, with subparallel sides slowly convergent ventrally, clypeus silver pruinose (Figures 2a-d); frons wider than high, indices: $0.66(\mathrm{~N}=2)$ (Figure 2e); flagellum dark.

Fronto-ocular area present, well developed, without infraocular suture, frontocular triangle absent (Figure 2f), antennae with $0.45-0.47 \mathrm{~mm}$, flagellum dark. Cibarium with well developed and highly sclerotised cornuae, with three or four rows of well sclerotised acuminate teeth medially, with pronounced central area depression without teeth (Figure $2 \mathrm{~g})$. Sensorial organ of maxillary palps with an irregular shape (Figure $2 \mathrm{~h}$ ), occupying one-half to nearly one-third length of basal article, palpomere $\mathrm{V}$ twice as long as palpomere IV, palpomere IV a little longer than the III (ratio III: IV: V 1:1.2: 2.36), maxillary lacinia with 12-14 external, one central and 7-9 (may reach one rudimentary tooth) internal retrorse teeth (Figure 2h). Mandible with 4-6 external serrations and 24-28 internal teeth (Figure 2i).

Thorax: wing length $1.5 \mathrm{~mm}$, width $0.7 \mathrm{~mm} ; \mathrm{Sc}$ and $\mathrm{R}_{2}$ wing veins with setae, $R_{1}$ without setae or spines in the basal half of the vein (Figure 2j).

Scutum with three black vittae bordered by silver pruinosity, the submedian silver stripes showing an elongated comma-shaped mark with an antero-lateral illumination (Figures 2b-c), with front superior illumination black median vittae narrower and more elongated posteriorly, submedian black vittae elongated anteriorly and comma-shaped marks shorter (Figure 2b); with posterior illumination black vittae slightly shorter and silver area increased with submedian bands reaching anterior scutal margin and lacking anterior comma- shaped marks (2a,d). Scutum pilosity golden, metanotum and scutellum black. Abdomen dark brown to black with $1+1$ silver spot on tergite II; tergites III-V velvet black with narrow latero-posterior area silver pruinose, T VI-VIII shiny and waxy. Forelegs brown, except external face of tibiae white, tarsi dark brown. Midlegs dark brown, except for basal articulation of tibiae and tarsi, cream; hind legs dark brown except for basal third of tibiae, basal two thirds of basitarsi and basal half of second tarsal segments cream. Calcipala and pedisulcus present, calcipala higher than wide, indices: 0.51 (Figure $2 \mathrm{k}$ ). All femora and tibiae with scales. Katepimerum and coxa with a group of sensillae (Figure 2l). Claws without sub-basal teeth (Figure $2 \mathrm{~m}$ ); cerci rounded, paraproct subrectangular, cercus higher than paraproct, (Figure $2 \mathrm{n}$ ), and gonapophysis with abundant microtrichiae, except the inner borders, slowly divergent below (Figure 2o), 10-14 setae per side of the sternite VIII. Genital fork stout and sclerotized, stem longer than the lateral arms, lateral arms forming a sub-triangular space (Figure 2p). Spermatheca subspherical, with cuticular internal microspines.

Male - General coloration and wings similar to female. Sensorial organ of maxillary palps small, subcircular (Figure $3 d$ ), occupying less than one-half to nearly one-third length of basal article, proportion ration of the palpomeres and the size of the antennae similar to the female. Scutum with $1+1$ black, submedian, silvery cunae extending for more than $3 / 4$ of scutum length, but not joining with silvery posterior area (Figure 3a-c); length of cunae change with the light position. Calcipala and pedisulcus present (Figure 3e). Genitalia in accordance with the morphology of this genus. Basistyle subquadrate about as long as high, dististyle subtriangular with strong club-shaped spine (Figure 3f); ventral plate with short basal arms and rounded border, coarse hairs covering most of ventral plate (Figure 3g); endoparamare with several large spines interspersed with smaller spines (Figure $3 \mathrm{~h}$ ).

Pupa - General coloration light brown, gill pale. Dorsal cocoon length 1.98-2.1 $\mathrm{mm}($ mean $=2.04 \mathrm{~mm} ; \mathrm{n}=5)$, ventral cocoon length $2.68-3.0 \mathrm{~mm}($ mean $=2.84 \mathrm{~mm} ; \mathrm{n}=5)$, gill length $1.38-1.68 \mathrm{~mm}($ mean $=1.53 \mathrm{~mm} ; \mathrm{n}=5)$. Cocoon light brown, slipper-shaped without anterior projection and covering gill base; cocoon made of soft and thick tissue with closely woven threads obscuring the pupa (Figure 4a).

Frontoclypeus with moderately abundant rounded platelets; $1+1$ long, hairlike, simple or bifid on the tip of the (Figures $4 \mathrm{~b}-\mathrm{c}$ ) facial trichomes and $2+2$ bifid frontal trichomes as long as facial trichomes (Figure $4 \mathrm{~b}$ ), external surface of antennal sheaths not covered with tubercles.

Gill with six filaments directed forwardly directed, main trunk small, giving rise to three branches, basal branch longer than the median branch that is a little longer than the dorsal branch. All the secondary branches divided in two terminal 

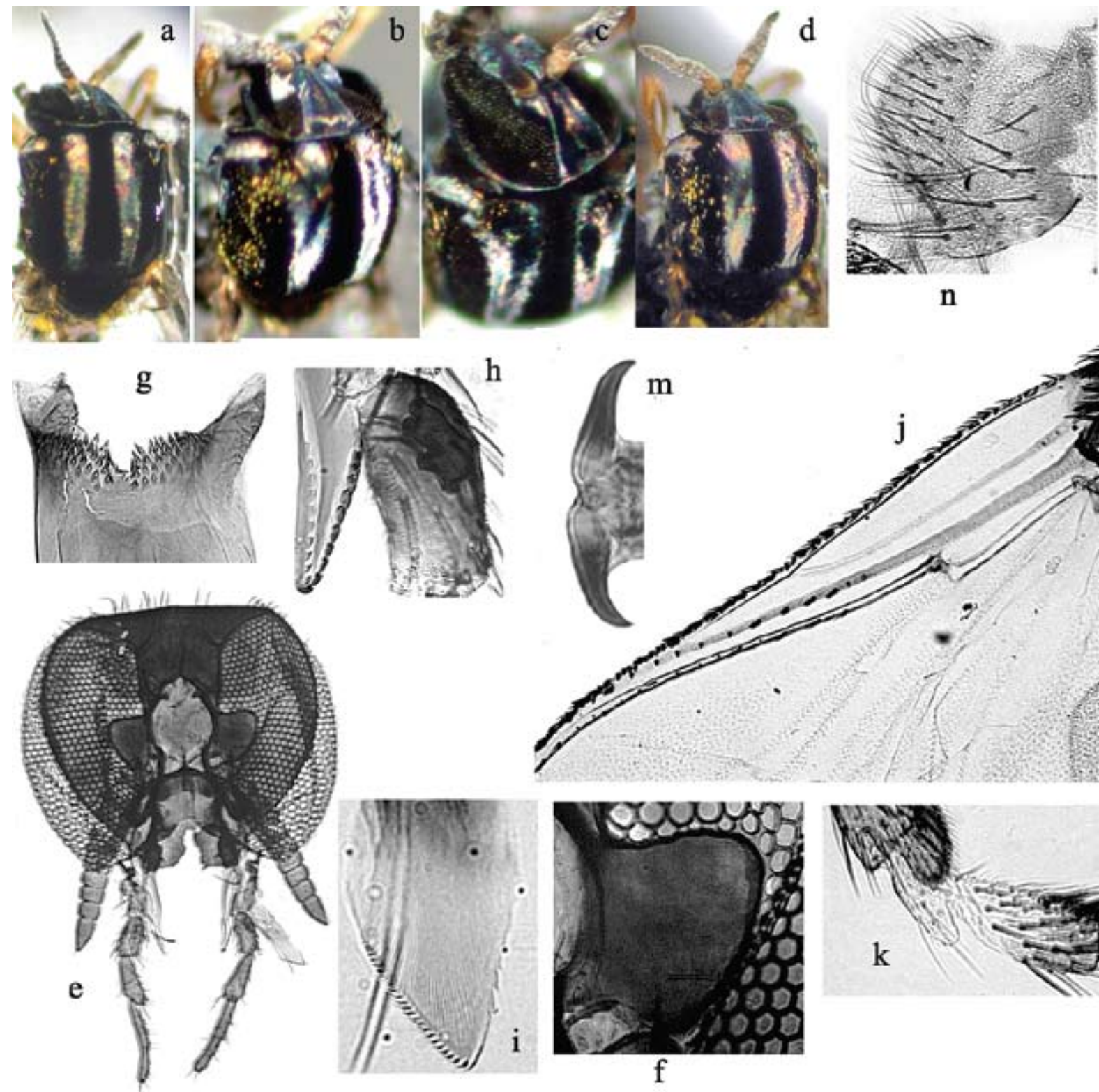

$\mathrm{n}$
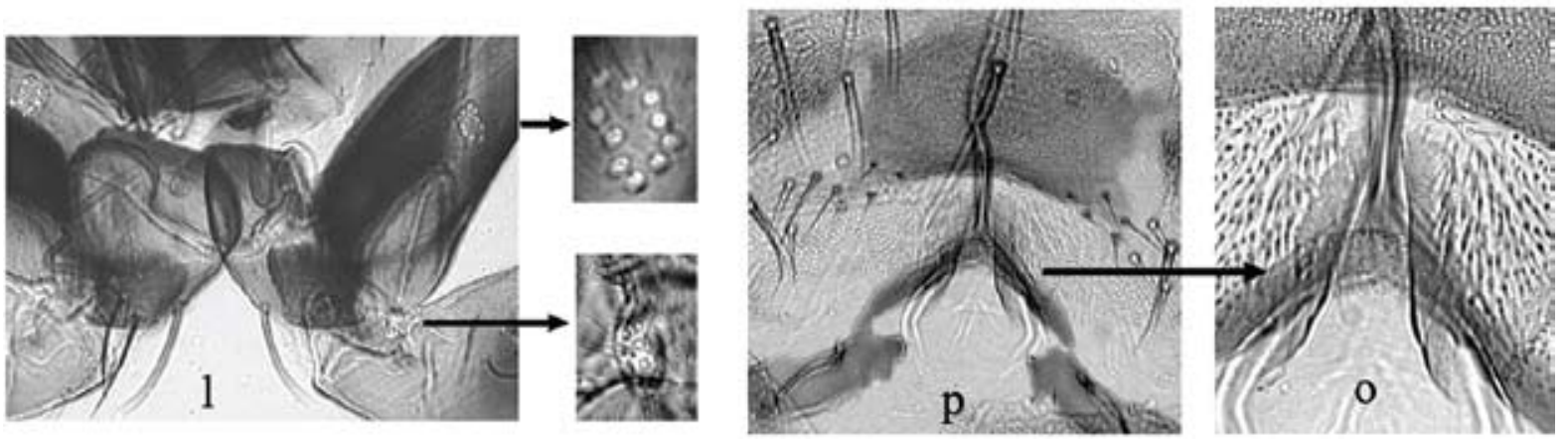

Figure 2 - Plate of female structures of Cerqueirellum pydanieli n. sp. a-d: Coloration of head and thorax. e: Head with dissected mouth parts; f: Fronto-ocular area; g: cibarium; h: sensorial organ of maxillary palps and maxillary lacinia; i: mandible; j: wing; K: calcipala and pedisulcus; l: katepimerum and coxa with a group of sensillae; m: claws; n: cercus; o: gonapophysis; $p$ : genital fork. 

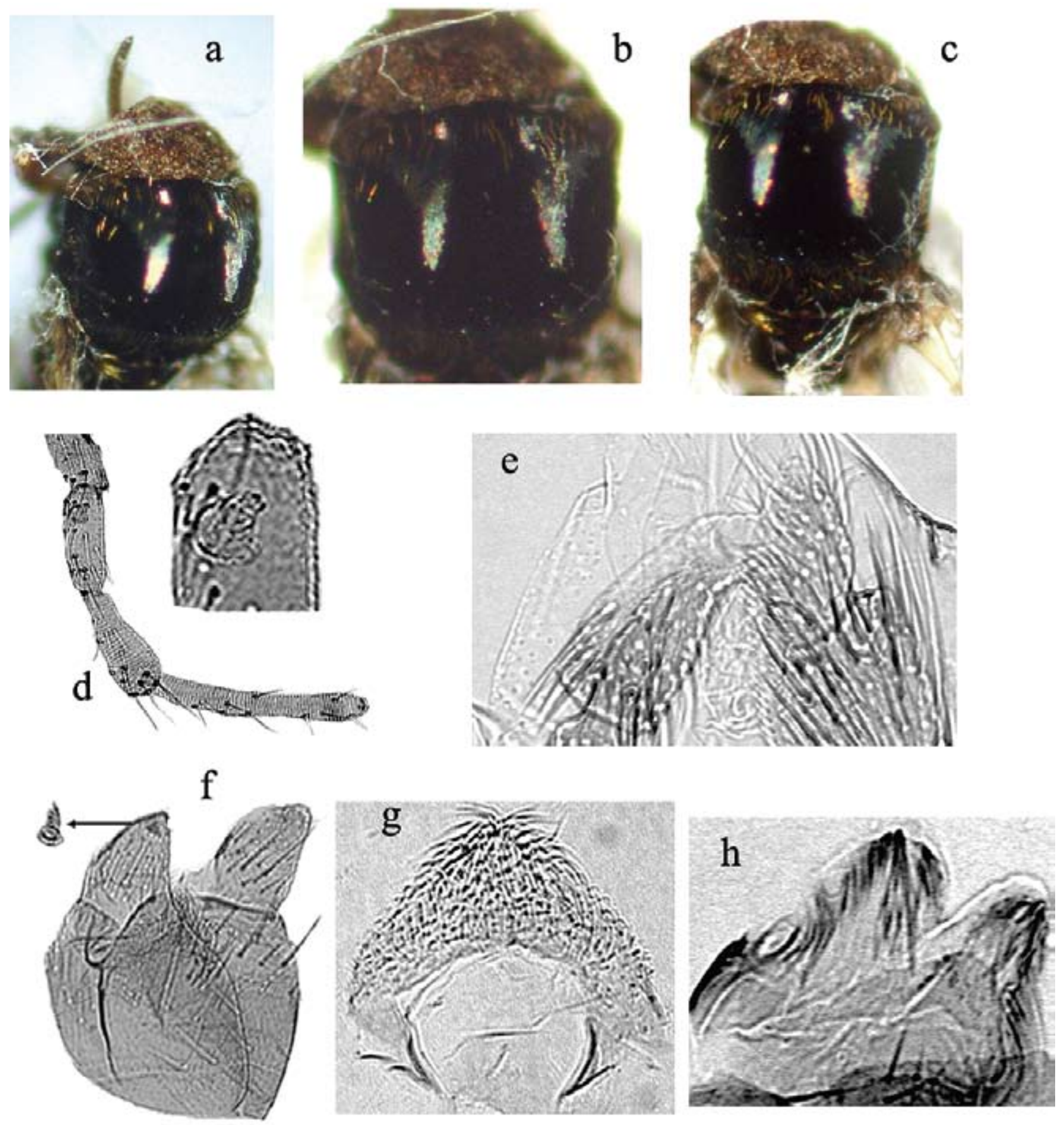

Figure 3 - Plate of male structures of Cerqueirellum pydanieli n. sp. a-c: General coloration of scutum; d: maxillary palp, increased segment showing the sensorial organ; e: calcipala and pedisulcus; f: basistyle and dististyle, arrow pointing to increased club-shaped spine; g: ventral plate; h: endoparamere. 
branches, equal or sub equal in length, gill formula $1[1(1+1)$ $+1(1+1)+1(1+1)]$; apex of all filaments digitiform (Figure $4 d)$.

Thorax with $5+5$ hair-like anterodorsal trichomes usually bifid but sometimes trifid, with coiled tip; $1+1$ supra-lateral, $3+3$ lateral simple hair-like trichomes. Platelets of the thorax moderately abundant, rounded, smaller than the point of insertion of thoracic trichomes (Figure $4 \mathrm{e}-\mathrm{f}$ ).

Abdominal tergite I with $1+1$ hairlike setae sublaterally; tergite II with $5+5$ spiniform setae; spine combs absent on tergites II and III. Tergites III and IV with $4+4$ anteriorly directed hooks on posterior margin, $1+1$ spiniform setae between the $1+1$ outermost hooks, and $2+2$ spiniform setae sublaterally; tergite $\mathrm{V}$ with $3+3$ submedian hair-like setae, tergites VI-VIII with $2+2$ submedian hairlike simple or bifid setae (Figure 4g) and with $1+1$ comb-like groups of small posteriorly directed spines on the anterior margin. Pleural membrane usually with 2-3 small simple setae per segment. Tergite IX with $1+1$ small curved terminal spur. Abdominal sternite III with $2+2$ lateral simple setae on anterior margin, and spines combs in the median region of anterior margin. Sternites IV-VIII with $1+1$ groups of spine combs in the median region of the anterior margin (Figure 4g). Sternites IV and $V$ with $1+1$ submedian simple to trifid small hooks (Figure $4 \mathrm{~h}$ ) and $2+2$ simple sub-median setae on anterior margin amongst groups of spine combs and $2+2$ sub-median setae lateral to outermost hooks; sternites VI-VII with $2+2$ simple to bifid sub-median hooks and $1+1$ simple setae between them. Sternites V to VII with longitudinal discrete median striations.

Larva (last instar) - length: $3.52-3.77 \mathrm{~mm}$ (mean $=3.64$ $\mathrm{mm} ; \mathrm{n}=5$ ); head capsule lateral length $0.48-0.52 \mathrm{~mm}$ (mean $=0.5 \mathrm{~mm} ; \mathrm{n}=5$ ). General coloration (in alcohol) white with dorsal greenish stripes through the body without fixed pattern (Figure 5a). Cephalic apotome yellow brownish without defined pattern spots, and with large multibranched setae (Figure 5b). Subesophageal ganglion pigmented.

Antennae longer than stem of cephalic fans (Figure 5c), distal, medial and proximal articles of subequal size, ratio (first article to third) 1: 1.14-1.17: 1.15-1.18 $(\mathrm{n}=5)$. Hypostomium with central tooth with same size as the $1+1$ corner teeth, $3+3$ intermediate teeth at same level, $2+2$ lateral teeth, 2-4 lateral serrations, 3-4 hypostomal setae per side, and 2-3 setae in the distal margin of hypostomal plate (Figure 5d). Postgenal cleft longer than wide, submitral, hypostomial bridge narrow. Proportion hypostoma/ hypostomal bridge/ postgenal cleft= 1: 0.25-0.35: 1.75-2 $(\mathrm{n}=5)$ (Figure 5e - f).

Cephalic fan with 28-34 primary rays, row of microtrichiae of the primary ray following the standard pattern (Palmer $\&$ Craig, 2000) (Figure 5g), as found in all species of the genus Cerqueirellum (Pessoa, 2004). Mandible with one apical, two external, three subapical teeth, 6-9 internal teeth apparently in a single row, the first internal tooth subequal to the first subapical tooth. Lateral mandibular process absent, one marginal tooth, fringe of supramarginal setae present (Figure $5 \mathrm{~h}$ ). Labral sclerite subtrapezoidal, covered with long setae and with $3+3$ apical teeth.

Proleg of thorax with lateral sclerites subrectangular, with an apical fringe of bristles, divided in 4 groups of combs with 3-5 bristles in each comb (Figure 5i). Gill histoblast in situ as in Figure 5j.

Abdomen with several simple to multibranched setae, sclerotized spines with a pointed or brushed tip, mainly distally on anterodorsum (Figure 5k-m); anal sclerite X-shaped, anterodorsal arms shorter in length than posteroventral arms, anal ring with 49-51 rows with 6-12 hooks on each; 1+1 ventral tubercles subtriangular present (Figure 5n).

Etymology - The species name pydanieli is in honor of Dr. Victor Py-Daniel, one of the most renowned South American black fly taxonomist and epidemiologist of Amazonian filariasis.

Taxonomic information - This new species is a member of the genus Cerqueirellum as defined by Py-Daniel (1983). The characters that justify its inclusion in this genus are: adult wings with setae on the basal region of $\mathrm{R}$ vein; basal portion of female cibarium with prominent teeth and central depression; and larva with the mandibles possessing supramandibular setae. The female and male of $C$. pydanieli n. sp. are very similar to C. ganalesense, $C$. oyapockense and $C$. roraimense. Coscarón \& Coscarón-Arias (2000) described the larva of $C$. oyapockense found in Argentina with the body integument having abundant palmate trichomes, but without stout spines, as found in C. pydanieli n. sp. Besides, C. oyapockense has two to three latero-mandibular processes while in the new species these process are absent. Stout spines in the dorsum of larvae can also be found in species of the genera Shelleyellum Py-Daniel \& Pessoa and Psaroniocompsa Enderlein but the larvae has no supramarginal setae in the mandible. The larva of $C$. roraimense has one latero-mandibular process and $C$. ganalesense has two. The pupae is easily separated by the facial trichomes, long, similar in length to the genera Psaroniocompsa and Coscaroniellum Py-Daniel, different from all other species of Cerqueirellum, of which the facial trichomes are short. Shelley et al. (2006) studied populations of simuliids from the Ituxi river and described the long facial trichomes probably of C. pydanielii n. sp., but apparently did not find or study the larvae, and identified this species as $C$. oyapockense and separated them, together with populations of the rivers Jacy Parana, tributary of the Madeira, and Madeira rivers, southern Amazonia and Ajarani and Toototobi, northern Amazonia. Also, the length of the gill of $C$. pydanieli n. sp. is closer to $C$. roraimense than $C$. oyapockense and where it is much shorter. 

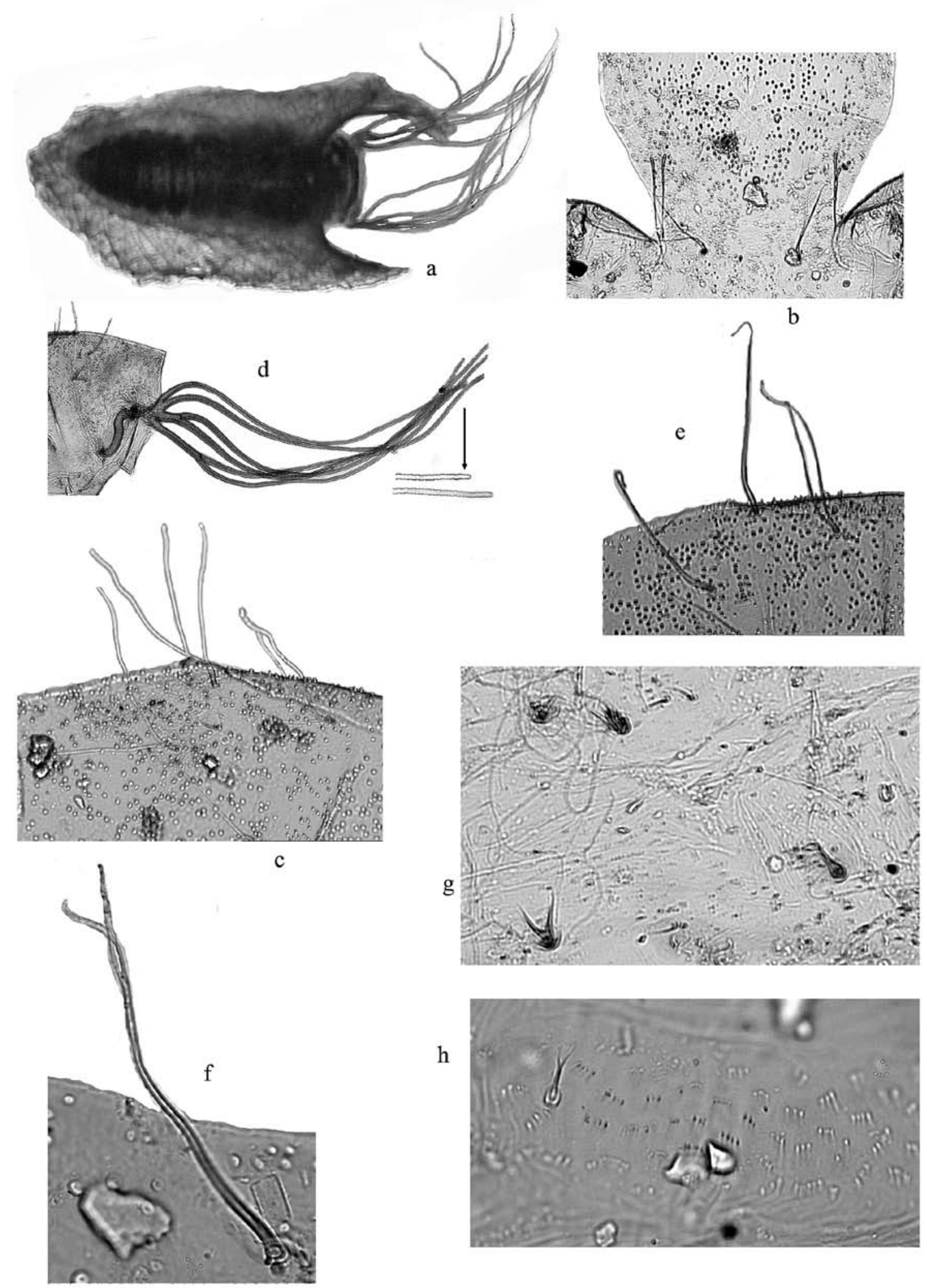

$\mathrm{h}$

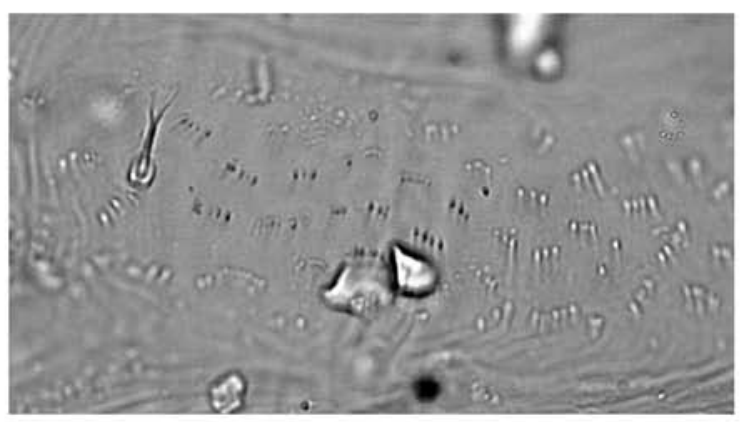

Figure 4 - Plate of pupal structures of Cerqueirellum pydanieli $\mathrm{n}$. sp. a: general appearance of the pupa; b: part of he frontoclypeus showing the trichomes; c: facial tricome, bifid; d: gill, arrow pointing to increased tip of the gill; e: and f: part of the thorax anterodorsal trichomes bifid and trifid, g: bifid setae of the tergite $\mathrm{V}$ and combs of microspines; $\mathrm{h}$ : hooks of the sternites IV and V. 
The basin of the Ituxi and Madeira rivers have large drainage channels, sculpted during the Pleistocene inundation lowland, after being separated by a neotectonic event (Souza Filho et al., 1999). Probably, as a recent event, the populations of both basins must be the same.

Remarks - The immatures were collected in tree roots and trunks fallen in the river. There are others species, $C$. amazonicum (Goeldi), biting humans along the Ituxi river, but this species was collected near the outlet of the river, a few kilometers from the Purus river. In the middle and high Ituxi, all immatures collected belong to the new species. The female scutal pattern also helped to identify females of $C$. pydanieli n. sp. from $C$. amazonicum. We captured 729 females of $C$. pydanieli and nine were parasitized with M. ozzardii larvae, with a $1.23 \%$ rate of parasitic infection. Seven flies contained $\mathrm{L}_{1}$ (36) and two $\mathrm{L}_{1}-\mathrm{L}_{2}(15)$ (Figure 6). All larval stages found were in the thorax of the simuliids. Our team found high rates of human mansonellialis (Medeiros et al., 2008), and probably C. pydanieli is involved with the transmission of $M$. ozzardi in the studied area.

\section{EXAMINED MATERIAL}

\section{Cerqueirellum pydanieli n.sp.}

Holotype, mounted on slide - Labelled as: INPA n 6297 pharate female and its respective pupal exuvia, Ituxi river, near the locality Majuriã, Lábrea municipality, Amazonas state, 20.08.2007, Collectors - Medeiros JF \& Barbosa UC. Paratypes: series of paratypes lalelled as: INPA ${ }^{\circ} 6297-1-$ 1 pinned female (reared), Ituxi river, near the locality Majuriã, Lábrea municipality, Amazonas state, 20.08.2007, Collectors - Medeiros JF \& Barbosa UC, respective pupal exuviae in alcohol; INPA ${ }^{\circ}$ 6297-2- 2 pinned female (reared), Ituxi river, near the locality Majuriã, Lábrea municipality, Amazonas state, 20.08.2007, Collectors Medeiros JF \& Barbosa UC; respective pupal exuviae in alcohol; INPA no 6297-2- 3 - pinned male (reared), Ituxi river, near the locality Majuriã, Lábrea municipality, Amazonas state, 20.08.2007, Collectors - Medeiros JF \& Barbosa UC; respective pupal exuviae in alcohol; INPA ${ }^{\circ}$ 6297-4 - pinned male (reared), Ituxi river, near the locality Majuriã, Lábrea municipality, Amazonas state, 20.08.2007, Collectors - Medeiros JF \& Barbosa UC; respective pupal exuviae in alcohol; INPA $n^{\circ}$ 6297-5 - mounted on slide pharate female and its respective pupa, Ituxi river, near the locality Ilha Verde, Lábrea municipality, Amazonas state, 20.08.2007, Collectors - Medeiros JF \& Barbosa UC; slide mounted - Biological Collection of the Instituto Leônidas \& Maria Deane-ILMD/FIOCRUZ-AM ( $\left.{ }^{\circ} 0002-1\right)$ - slide mounted - pharate female and its respective pupa, Ituxi river, near the locality Ilha Verde, Lábrea municipality,
Amazonas state, 20.08.2007, Collectors - Medeiros JF \& Barbosa UC; slide mounted - INPA no 6297-6 -pharate male and its respective pupa, Ituxi river, near the locality Ilha Verde, Lábrea municipality, Amazonas state, 20.08.2007, Collectors - Medeiros JF \& Barbosa UC; ILMD/FIOCRUZ-AM ( ${ }^{\circ}$ 0002-2) - slide mounted pharate male and its respective pupa, Ituxi river, near the locality Ilha Verde, Lábrea municipality, Amazonas state, 20.08.2007, Collectors - Medeiros JF \& Barbosa UC; slide mounted - INPA $n^{\circ}$ 6297-7 - mature larva, Ituxi river, near the locality Majuriã, Lábrea municipality, Amazonas state, 20.08.2007, Collectors - Medeiros JF \& Barbosa UC; slide mounted - INPA n ${ }^{\circ}$ 6297-8 - mature larva, Ituxi river, near the locality Majuriã, Lábrea municipality, Amazonas state, 20.08.2007, Collectors - Medeiros JF \& Barbosa UC; slide mounted - Biological Collection of the Instituto Leônidas \& Maria Deane ILMD/FIOCRUZ-AM $\left(\mathrm{n}^{\circ}\right.$ 0002-3) - mature larva, Ituxi river, near the locality Majuriã, Lábrea municipality, Amazonas state, 20.08.2007, Collectors - Medeiros JF \& Barbosa UC; slide mounted Biological Collection of the Instituto Leônidas \& Maria Deane ILMD/FIOCRUZ-AM ( ${ }^{\circ}$ 0002-4) - mature larva, Ituxi river, near the locality Majuriã, Lábrea municipality, Amazonas state, 20.08.2007, Collectors - Medeiros JF \& Barbosa UC; slide mounted - INPA n ${ }^{\circ} 6297-9$ - pupa, Ituxi river, near the locality Majuriã, Lábrea municipality, Amazonas state, 20.08.2007, Collectors - Medeiros, JF \& Barbosa UC; slide mounted - INPA n ${ }^{\circ}$ 6297-10 - pupa, Ituxi river, near the locality Majuriã, Lábrea municipality, Amazonas state, 20.08.2007, Collectors - Medeiros JF \& Barbosa UC; slide mounted - INPA n 6297-9 - pupa, Ituxi river, near the locality Majuriã, Lábrea municipality, Amazonas state, 20.08.2007, Collectors - Medeiros JF \& Barbosa UC; Biological Collection of the Instituto Leônidas \& Maria Deane ILMD/FIOCRUZ-AM (n ${ }^{\circ} 0002-5$ ) pupa, Ituxi river, near the locality Ilha Verde, Lábrea municipality, Amazonas state, 20.08.20074, Collectors - Medeiros JF \& Barbosa UC; Biological Collection of the Instituto Leônidas \& Maria Deane ILMD/FIOCRUZ-AM (n $\left.{ }^{\circ} 0002-6\right)$ pupa, Ituxi river, near the locality Ilha Verde, Lábrea municipality, Amazonas state, 20.08.2007, Collectors - Medeiros JF \& Barbosa UC; spirit material labelled as - material in alcohool, - INPA n ${ }^{\circ}$ 6297-11 - 10 larvae and 10 pupae in alcohol Ituxi river, near the locality Ilha Verde, Lábrea municipality, Amazonas state, 22.08.2007, Collectors Medeiros JF \& Barbosa UC.

\section{Cerqueirellum ganalesense:}

Type series of the INDRE (Instituto Nacional de Diagnóstico y Referência Epidemiológicos): México, San Luis Potosí, Município de Guerrero, Hancieda de Ganales col. 

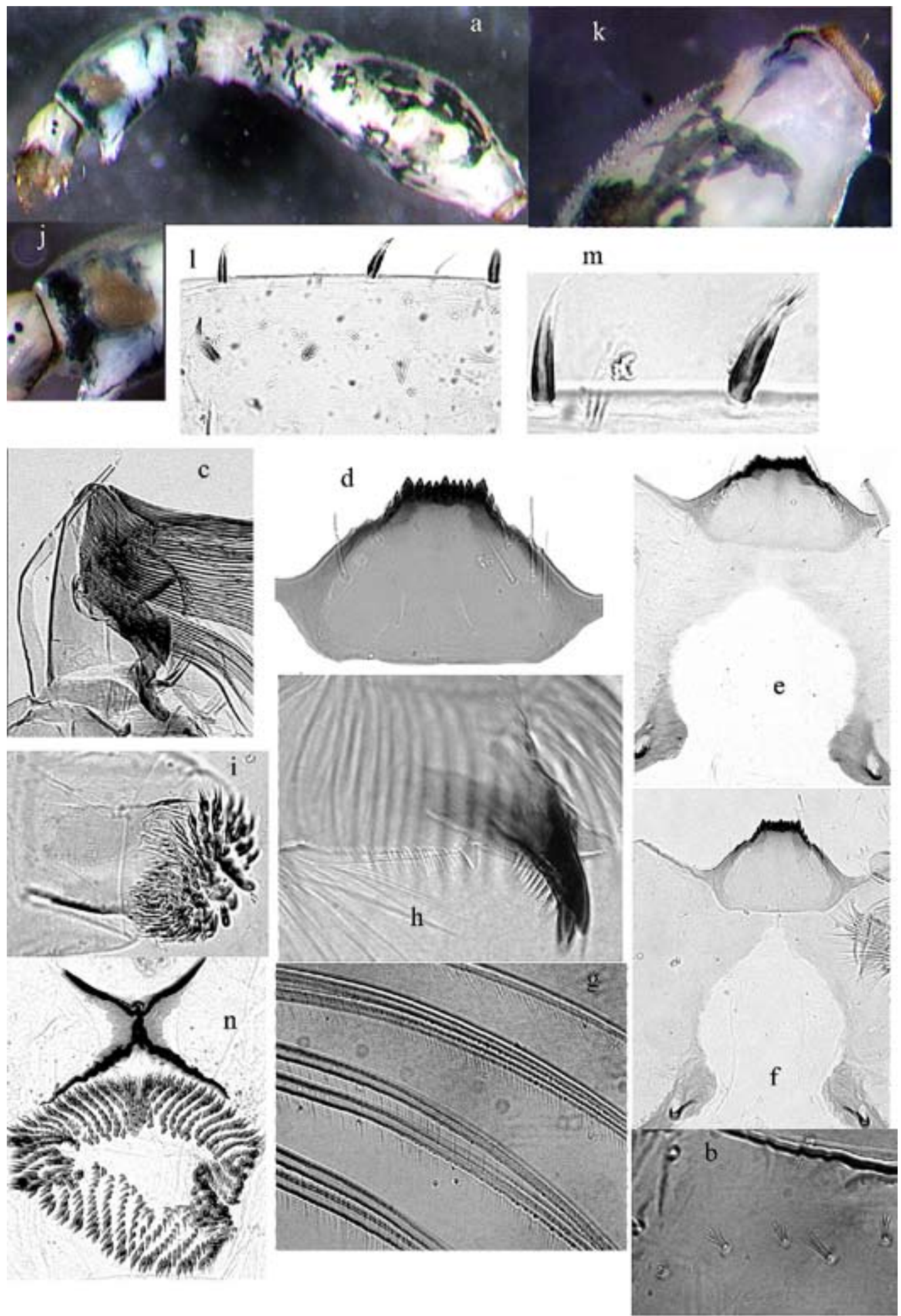

Figure 5 - Plate of larval structures of Cerqueirellum pydanieli $\mathrm{n}$. sp. a: general coloration and shape of the larva; b: setae of cephalic apotome; c: antenna and stem of cephalic fan; d: hypostomium; e-f: hypostomium, hypostomial bridge and postgenal cleft; g: rows of microtrichiae of the primary ray of the cephalic fan, h: mandible, arrow pointing the fringe of supramarginal setae; i: proleg of thorax with lateral sclerites; j: gill histoblast; k: abdomen with several simple to multibranched setae, sclerotized spines with a pointed or brushed tip; I and m: increased area of abdomen, showing the several types of spines and setae; $n$ : anal sclerite and anal ring. 


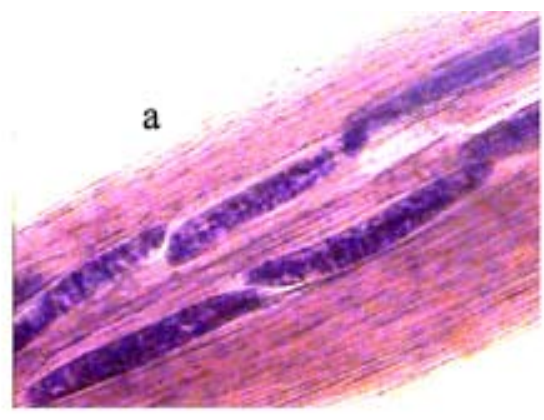

$\mathrm{b}$

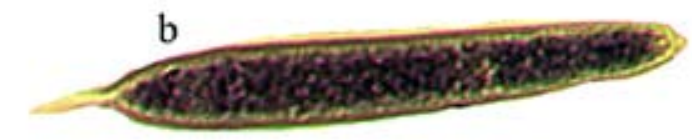

c

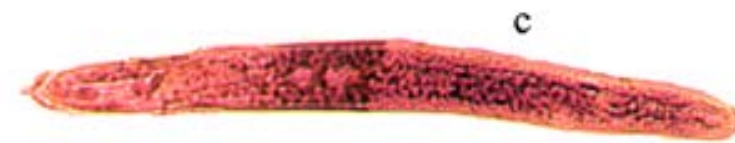

Figure 6 - Larval forms of Mansonella ozzardii found in collected females of Cerqueirellum pydanieli $\mathrm{n}$. $\mathrm{sp}$.: a - Form $\mathrm{L}_{1}$ in the thoracic muscles of females; b: isolated $\mathrm{L}_{1}$; c: isolated $\mathrm{L}_{1}-\mathrm{L}_{2}$.

M. Mácias (Del. \# 62 al 65), 11/04/44; 5 larvae, 2 males, 2 females, 4 pupae, slide mounted 2 males, 2 females, 3 larvae and 2 pupae.

\section{Cerqueirellum oyapockense:}

Slide mounted topotypes: Laboratório of EtnoEpidemiologia (LETEP) - INPA - 5861-F: 2-exuviae, cocoon, female, 1pupa; No 5861, 3- larvae, No 5861-B: 2Larvae, 5861-D: 2-exuviae + 2-cocoon, 5861-C: exuviae + cocoon + female, 5861-G: exuviae + cocoon + female, topotype; No 5861-F: Larva, No 5861-F: Exuviae, Pupa, Salto Cafésoca-Maripá, Oiapoque river, French Guyana; 24-25/11/1981), collector Py-Daniel V.

\section{Cerqueirellum roraimense:}

In alcohol, labelled as: Locality: Cauomé river, $3 \mathrm{Km}$ da Br - 174, Boa Vista, Roraima, 26/11/1972, LETEP- INPA (5881-1; type material: contends a pupal exuvia and cocoon; in slides: holotype: 1 male and its respective pupal exuvia, labbelled as Cauomé river, $3 \mathrm{Km}$ da $\mathrm{Br}-174$, Boa Vista, Roraima, 26/11/1972, LETEP- INPA (5881). Paratypes: 3 pupal exuviae, labelled as LETEP - INPA 5881-2, same dates of the holotype, spirit material: LETEP- INPA 5881-3 pharate male; 1 pharate female, labbelled with same dates of the holotype) Collectors - Nunes de Mello \& Silva.

\section{ACKNOWLEDGMENTS}

The Fundação de Amparo a Pesquisa do Amazonas, FAPEAM, project "Perfil Epidemiológico da Mansonelose em Comunidades Ribeirinhas nos Municípios de Lábrea, Pauini e Boca do Acre no Estado do Amazonas, Brasil”, № 2205/05, for funding. Claudia Maria Rios-Velásquez, for the images of the black flies.

\section{LITERATURE CITED}

Coscarón, S.; Coscarón-Arias, C.L. 2000. New species records for the blackfly (Diptera-Simuliidae) fauna of Argentina with description of adults, pupa and larva of Simulium oyapockense s.l. and S. seriatum. Memórias do Instituto Oswaldo Cruz, 95(2):179-187.

Coscarón, S.; Coscarón-Árias, C.L. 2007. Neotropical Simuliidae (Diptera: Insecta) In: Adis, J.; Arias, J.R.; Rueda-Delgado, G.; K.M. Wantzen (eds.): Aquatic Biodiversity in Latin America (ABLA). Vol. 3. Pensoft, Sofia-Moscow, 685pp.

Medeiros, J.F.; Py-Daniel, V.; Barbosa, U.C.; Ogawa, G.M. 2008. Current profile of Mansonella ozzardi (Nematoda: Onchocercidae) in communities along the Ituxi river, Lábrea municipality, Amazonas, Brazil. Memórias do Instituto Oswaldo Cruz, 103(4): 409-411.

Palmer, R.W.; Craig, D.A. 2000. An ecological classification of primary labral fans of filter-feeding black fly (Diptera: Simuliidae). Canadian Journal of Zoology, 78: 199-218.

Pessoa, F.A.C. 2004. Revisão e análise dos gêneros Cerqueirellum Py-Daniel (1983) e Coscaroniellum Py-Daniel (1983) (Diptera: Simuliidae). Tese de Doutorado, Instituto Nacional de Pesquisas da Amazônia/Fundação Universidade do Amazonas, Manaus, Amazonas. 329pp.

Py-Daniel, V. 1983. Caracterização de dois novos subgêneros em Simuliidae (Diptera: Culicomorpha) neotropical. Amazoniana, 8(2): 159-223.

Py-Daniel, V.; Coscarón, S. 2001. Simuliidae (Diptera: Culicomorpha) no Brasil III. Sobre o Coscaroniellum ulyssesi sp. n. Entomologia $y$ Vectores, 8(1): 51-64.

Shelley, A.J.; Lowry, C.A.; Maia-Herzog, M.; Luna Dias, A.P.A.; Moraes, M.A.P. 1997. Biosystematic studies on the Simuliidae (Diptera) of the Amazonia onchocerciasis focus of Brazil. Bulletin Natural History Museum (Ent.), 66: 1-121.

Shelley, A.J.; Hernández, L.M.; Penn, M. 2002. A biosystematic revision of the blackflies (Diptera: Simuliidae) of Belize, Central America. Bulletin Natural History Museum. (Ent.), 71: 135-271.

Shelley, A.J.; Hernández, L.M.; Maia-Herzog, M.A.; Luna Dias, A.P.A.; Luz, S.B. 2006. An interpretation of the morphological variation in the Simulium amazonicum species group (Diptera: Simuliidae) of Latin America Zootaxa, 1274:1-68.

Souza Filho, P.W.M.; Quadros, M.L.E.S.; Scandolara, J.E.; Silva Filho, E.P.; Reis, M.R. 1999. Compartimentação morfoestrutural e neotônica do sistema fluvial Guaporé-Mamoré - Alto Madeira, Rondônia - Brasil. Revista Brasileira de Geociências, 29(4): 469-476.

Recebido em 25/03/2008 Aceito em 17/09/2008 